\title{
Risk Factors Associated with Acinetobacter baumannii Infections in Patients in an Intensive Care Unit of a Public Hospital in Paraná
}

\author{
Mirian Carla Bortolamedi da Silva ${ }^{1,2}$ (D), Maria Helena Brandeleiro Werlang1,2, \\ Valdir Spada Júnior ${ }^{1,2}$, Guilherme Welter Wendt', Ana Paula Vieira1, \\ Franciele Ani Caovilla Follador ${ }^{1}$, Léia Carolina Lucio ${ }^{1}$, Cleide Viviane Busanello Martinss, \\ Kérley Braga Pereira Bento Casaril ${ }^{1}$, Paulo Cezar Nunes Fortes ${ }^{1}$, Lirane Elize Defante Ferreto ${ }^{1}$
}

${ }^{1}$ Post-Graduante Program, Health Sciences, University of Wester Paraná (UNIOESTE), Francisco Beltrão, Brazil

${ }^{2}$ State of the Health of Paraná (SESA-PR), Francisco Beltrão, Brazil

Email: mirian.silva@hotmail.com

How to cite this paper: da Silva, M.C.B., Werlang, M.H.B., Spada Jr., V., Wendt, G.W., Vieira, A.P., Follador, F.A.C., Lucio, L.C., Martins, C.V.B., Casaril, K.B.P.B., Fortes, P.C.N. and Ferreto, L.E.D. (2022) Risk Factors Associated with Acinetobacter baumannii Infections in Patients in an Intensive Care Unit of a Public Hospital in Paraná. Advances in Infectious Diseases, 12, 90-105. https://doi.org/10.4236/aid.2022.121008

Received: January 21, 2022

Accepted: March 1, 2022

Published: March 4, 2022

Copyright $\odot 2022$ by author(s) and Scientific Research Publishing Inc. This work is licensed under the Creative Commons Attribution International License (CC BY 4.0).

http://creativecommons.org/licenses/by/4.0/

\begin{abstract}
To identify risk factors for $A$. baumannii infection in patients hospitalized in an Intensive Care Unit (ICU) of a tertiary public hospital in Paraná, Brazil, a retrospective paired case-control study (ratio 1:2) was conducted from January 2018 to December 2020. Patients in the case group were hospitalized in the ICU with $A$. baumanni ( $\mathrm{n}=68$ cases) and were compared with patients in the control group, without infection by $A$. baumannii $(\mathrm{n}=136)$. Both were matched by age ( \pm 10 years), sex, and ICU stay ( \pm 5 days). Conditional multiple logistic regression was used to determine statistically significant risk factors based on the results of bivariate analyses. Mortality was higher in infected (cases) than in non-infected patients (51.5\% vs. $39.7 \%$ ). The incidence and bacterial resistance increased annually. At bivariate analysis, cases had longer hospital stays (median 35 vs. 22 days, $\mathrm{p}<0.001$ ) and remained longer in the ICU (median 23 vs. 16 days, $\mathrm{p}<0.001$ ). Longer use of a central venous catheter (median 25 vs. 18 days, $\mathrm{p}<0.001$ ), the vesical catheter (median 29 vs. 20 days, $\mathrm{p}<0.001$ ), and mechanical ventilation (median 17 vs. 12 days, $\mathrm{p}<$ 0.001 ) were found among cases. Cases also presented a higher frequency of admission by transfer from another unit $(\mathrm{p}<0.001)$, previous hospitalization $(\mathrm{p}=0.011)$, colonization $(\mathrm{p}<0.001)$, surgical procedure $(\mathrm{p}=0.013)$, and use of an enteral tube $(\mathrm{p}=0.011)$ than controls. The multivariate analysis showed that hospitalization time $\left(\mathrm{OR}=1.06 ; \mathrm{CI}_{95 \%}: 1.03-1.08\right)$, transfer from another unit $\left(\mathrm{OR}=5.03 ; \mathrm{CI}_{95 \%} 2.30-10.98\right)$ and colonization $\left(\mathrm{OR}=9.32 ; \mathrm{CI}_{95 \%} 3.52\right.$ 24.72) were independently associated with infection. The study revealed an
\end{abstract}


increase in infections by $A$. baumannii and antimicrobial resistance. There is need for surveillance, and constant evaluation of control actions. Risk factors were colonization, previous hospitalization, and hospitalization time. This is essential for the decision-making of professionals and optimization of prevention, control, and therapeutic management actions.

\section{Keywords}

Acinetobacter baumannii, Risk-Factors, Infection, Intensive Care

\section{Introduction}

Care-related infections have been reported exponentially worldwide, mainly $A$ baumannii is an emerging nosocomial pathogen that causes severe infections in hospitalized patients [1]. It was defined as a critical priority by the World Health Organization (WHO), for its ability to rapidly develop antimicrobial resistance mechanisms [2] [3]. The mechanisms responsible for development and transference are the occurrence of mutation and the presence of transferable genetic material (plasmid, transposons, and integrons), inadequate and indiscriminate use of antimicrobials in human and animal health, which might result in resistant strains that require effective interventions to minimize associated problems [4].

Data from 2017 from the Centers for Disease Control and Prevention (CDC) indicate that in the United States in 2017, there were 8500 cases of $A$. baumannii infections with 700 deaths [5]. In Brazil, studies have shown that $A$. baumannii is widely disseminated and with high resistance to imipenem ranging from $81 \%$ to $91.9 \%$ and colistin sensitivity of $98.8 \%$. Mortality rates ranged from $43.7 \%$ to $81 \%$ in those infected with A. baumanni [6] [7] [8]. In Paraná, data from 2018 and 2019 Online Hospital Infection Notification System (SONIH), showed that the Acinetobacter baumannii Complex ranked fifth position among reported microorganisms, moving upwards to the second position in 2020. During the first quarter of 2021, in the presence of the COVID-19 pandemic, there was a $90 \%$ increase in the shipment of resistant clinical isolates when compared to 2019 and $99 \%$ were resistant to carbapenems. Resistance to polymyxin reached $20 \%$ of the isolates in the period [9] [10] [11].

In a previous study conducted at the same institution, it was found that $A$. baumanni is endemic in the health service, reinforcing the findings of the literature that the longer hospitalizations, the transfer of other hospital services, and pneumonia associated with mechanical ventilation were considered significant risk factors for the presence of multidrug-resistant $A$. baumanni. It was found that $72.4 \%$ of the cases of $A$. baumannii were detected in the ICU, reinforcing the importance of a study directed to this hospitalization ward, since it aggregates all factors considered relevant to the presence of the bacterium and the 
worst outcome to the patient [12]. Thus, the study was intended to identify the risk factors for infection by $A$. baumannii in patients in an Intensive Care Unit of a Public Hospital of Paraná.

\section{Materials and Methods}

\subsection{Research Design}

A paired case-control study with retrospective inclusion of cases and simultaneous selection of controls (1:2 ratio) was adopted.

\subsection{Participants and Procedures for Data Collection}

A case was defined as a patient that was hospitalized in an intensive care unit (ICU) and had positive for $A$. baumannii resistant to more than three classes of antimicrobials. Two controls were individually matched for each case by age ( \pm 10 years), gender and ICU stay ( \pm 5 days). The controls were selected among patients with negative for $A$. baumanni (Figure 1).

Data collection occurred from January 2018 to December 2020, at the Walter Alberto Pecóits Regional Hospital, which has 130 beds, exclusively accredited by the Unified Health System (SUS), of which 20 pertains to the ICU.

Data were collected from secondary sources, electronic medical records, intensive care unit records, and hospital infection control centers of patients treated by the study service, which were grouped into: demographic and hospitalization data, age, gender, year, ICU stay, the form of admission (referred from another hospital or direct from the community), diagnosis of hospitalization (morbidity) and the number of comorbidities. Prognostic index, Estimated

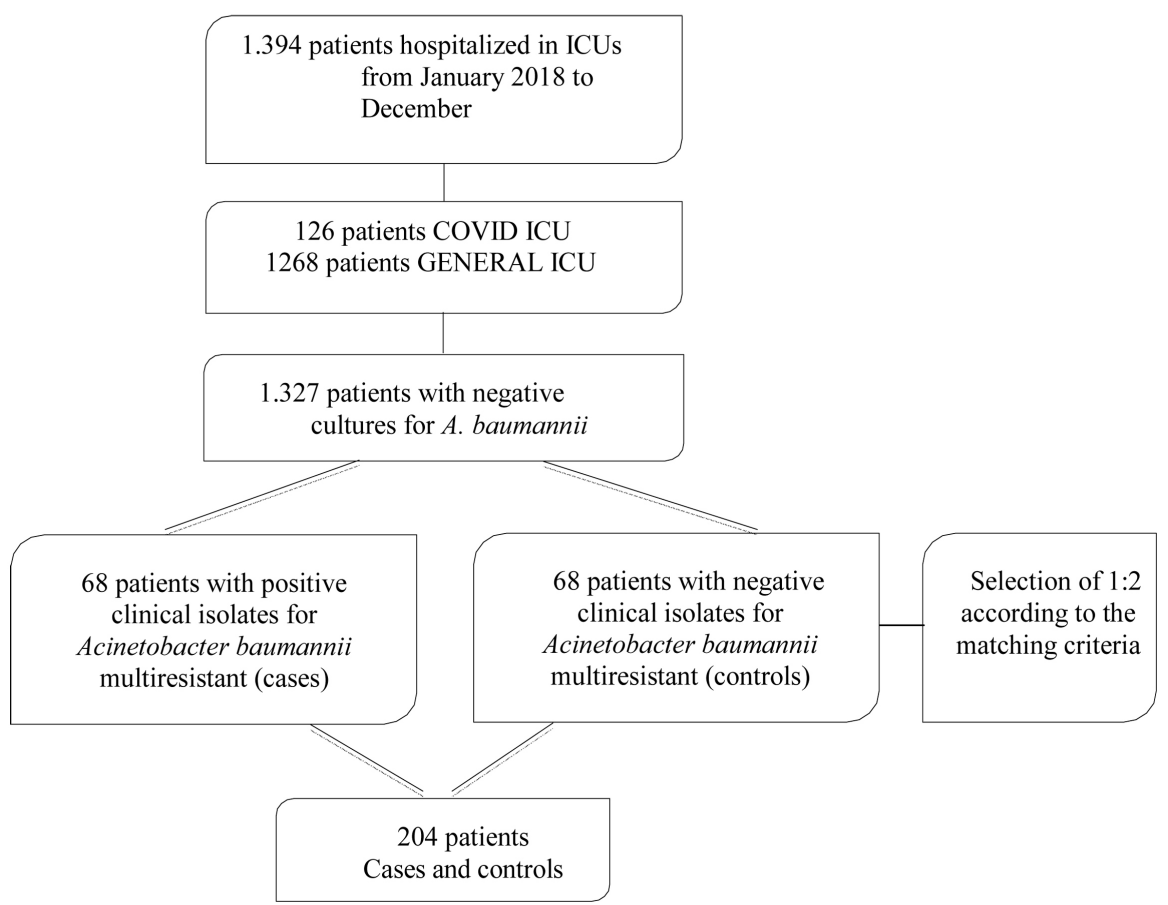

Figure 1. Study recruitment flowchart and case and control screening process. 
percentage of death predicted by APACHE II at admission considering the clinical picture. Risk factors, recent previous hospitalization, use of invasive devices (catheter venous central, catheter vesical, and intubation), time of use of each device: days of use of the central venous catheter (CVC), of the vesical catheter (SVD), of the mechanical ventilation (VM) and use of an enteral tube. Hemodialysis procedure, previous antimicrobial use, and surgical procedure. Microbiological data, colonization, infection, isolated microorganism, antimicrobial resistance profile, site of infection (tracheal aspirate, nasal and rectal swab, blood culture, catheter tip, urine, wound, scar, pleural fluid), internment time until colonization and patient outcome (hospital discharge/death). The clinical isolates were obtained from the identification of signs and symptoms of suspected sepsis in patients hospitalized in the general ICUs and COVID ICU in the period. Surveillance cultures were performed at the time of admission and later every week in those with previous negative results.

Microbiological information was obtained from the laboratory reports of the school laboratory UNISEP (2018) and Biolabor (2019-2020) and epidemiological surveillance records of the Hospital Infection Control Commission (CCIH). Microbiological analyses were performed by manual disc-diffusion tests and microdilution polymyxin testing by the UNISEP Laboratory in 2018, following the criteria of the sensitivity protocol of the Clinical Laboratory Standards Institute (CLSI) [13]. From 2019, semi-automated analysis began with Micro Scan 4, microdilution polymyxin test, and PCR (polymerase chain reaction) is performed using the protocol of The European Committee on Antimicrobial Susceptibility Testing (EUCAST) [14]. According to SESA Resolution No. 0674/2010 and SESA Resolution No. 096/2018, the positive samples were sent to the Central Laboratory of Paraná (LACEN-PR), for genetic research, performed automated proves with ${ }^{\star}$ Vitek 2 and PCR for research of the bla_OXA-23 [15] [16].

\subsection{Data Analyses and Ethical Aspects}

Descriptive analyses were performed, using absolute (n) and relative (\%) frequencies for categorical variables and measures of central tendency (mean and median) and dispersion (standard pattern and interquartile interval) for quantitative variables. The Kolmogorov-Smirnov test was used to test the distribution of the data. Since the assumption of normal distribution was not met for most variables, the Mann-Whitney test was used to compare quantitative variables between cases and controls. The chi-square test with Yates's continuity correction was used to verify the association between the categorized risk factors (independent variables) and infection by $A$. baumannii (case/control). After the crude analyses, binary logistic regression models were constructed to identify the main factors associated with $A$. baumannii infection. Initially, the variables with $\mathrm{p}<0.20$ in the crude analyses were tested individually in the models. Next, the final model (multivariate) was constructed with the manual input of the variables from the highest to the lowest odds ratio. Only the variables remained in 
the adjusted model, which remained significant $(\mathrm{p}<0.05)$. Thus, the results of the adjusted odds ratio and $95 \%$ confidence interval (logistic regression indicators) are presented only for the variables that comprised the final model. All analyses were performed in the SPSS 25.0 program.

The project was submitted for approval to the Ethics and Research Committee of the State University of Western Paraná (UNIOESTE), Opinion No. 4.681.274, and the Ethics and Research Committee of the coparticipant institution, Opinion No. 4.709.284.

\section{Results}

During the study period, a total of 1.394 patients were hospitalized in the General ICUs and COVID. 67 cases and 134 controls were included (Table 1). In the case group, all isolates were resistant to carbapenems, and none were resistant to polymyxin. The aminoglycosides had an annual increase in resistance between $2018(\mathrm{n}=1), 2019(\mathrm{n}=7)$, and $2020(\mathrm{n}=13)$. Colonization occurred in 25 patients, of these $60 \%(\mathrm{n}=15)$, had a diagnosis of infection by $A$. baumannii. On the nasal swab and rectal swab collection for surveillance at ICU admission, 26.7\% $(\mathrm{n}=4)$ presented intestinal colonization.

Table 1 shows the main characteristics of cases and controls, unspecified trauma was the most common cause of hospitalization, while respiratory disorders were the second leading cause among cases and septicemia was among controls. Regarding the site of infection, almost $70 \%$ of the positive isolates for A. baumannii were aspirated tracheal, while a percentage of $10.3 \%$ of the controls had an infection. Finally, we observed a slightly longer time from hospitalization to colonization and a higher proportion of deaths among cases.

The cases presented longer hospitalization time, longer ICU time, in addition to a greater number of days using the central venous catheter, the urinary catheter, and mechanical ventilation when compared to controls. In addition, the cases presented a higher frequency of admission by transfer from another health unit, previous hospitalization, colonization, surgical procedure, and use of enteral catheter than controls (Table 2).

After the crude analyses, Table 3 shows the logistic regression models with the main factors associated with Infection by $A$. baumannii in an adjusted manner. Considering the final model, the time of hospitalization, the form of hospital admission, and colonization were independently associated with the outcome. The main predictor was colonization, with an odds ratio almost 10 times higher in cases than in controls. In addition, we observed that each day of hospitalization increases by $6 \%$ the chance of infection by $A$. baumannii and that admission by transfer from another health unit increased 5 times the chances of infection.

\section{Discussion}

A. baumanni is an etiological agent defined as of critical interest in ICUs by the WHO, due to its ability to develop rapid resistance to multiple antimicrobials 
Table 1. General characteristics of cases $(n=68)$ and controls $(n=136)$ hospitalized in an ICU in a Public Hospital in Paraná, Brazil from January 2018 to December 2020.

\begin{tabular}{|c|c|c|c|c|}
\hline \multirow[b]{2}{*}{ Variable } & \multirow{2}{*}{$\begin{array}{c}\text { Case }(n=68) \\
n\end{array}$} & \multicolumn{3}{|c|}{ Control $(n=136)$} \\
\hline & & $\%$ & $\mathbf{n}$ & $\%$ \\
\hline \multicolumn{5}{|l|}{ Sex } \\
\hline Male & 46 & 67.6 & 92 & 67.6 \\
\hline Female & 22 & 32.4 & 44 & 32.4 \\
\hline \multicolumn{5}{|l|}{ Age } \\
\hline Up to 60 years & 28 & 41.2 & 50 & 36.8 \\
\hline More than 60 years & 40 & 58.8 & 86 & 63.2 \\
\hline \multicolumn{5}{|l|}{ Year } \\
\hline 2018 & 13 & 19.1 & 26 & 19.1 \\
\hline 2019 & 18 & 26.5 & 36 & 26.5 \\
\hline 2020 & 37 & 54.4 & 74 & 54.4 \\
\hline \multicolumn{5}{|l|}{ Diagnosis of hospitalization } \\
\hline Digestive tract disease & 8 & 11.8 & 10 & 7.4 \\
\hline Unspecified trauma & 19 & 27.9 & 33 & 24.3 \\
\hline Cardiovascular disease & 4 & 5.9 & 19 & 14.0 \\
\hline Septicemia & 8 & 11.8 & 25 & 18.4 \\
\hline Respiratory disorder & 16 & 23.5 & 13 & 9.6 \\
\hline Genitourinary system disease & 5 & 7.4 & 13 & 9.6 \\
\hline High-risk pregnancy woman & 1 & 1.5 & 0 & 0.0 \\
\hline Neurological disorder & 2 & 2.9 & 13 & 9.6 \\
\hline Covid-19 & 5 & 7.4 & 10 & 7.4 \\
\hline \multicolumn{5}{|l|}{ Site of infection } \\
\hline None & 11 & 16.2 & 104 & 76.5 \\
\hline Tracheal aspiration & 46 & 67.6 & 14 & 10.3 \\
\hline Blood cultures & 1 & 1.5 & 7 & 5.1 \\
\hline Urine & 8 & 11.8 & 11 & 8.1 \\
\hline Wound & 2 & 2.9 & 0 & 0.0 \\
\hline \multicolumn{5}{|c|}{ Internment time until colonization } \\
\hline Up to 10 days & 10 & 40.0 & 5 & 62.5 \\
\hline More than 10 days & 15 & 60.0 & 3 & 37.5 \\
\hline \multicolumn{5}{|l|}{ Outcome } \\
\hline Death & 35 & 51.5 & 54 & 39.7 \\
\hline Discharge & 33 & 48.5 & 82 & 60.3 \\
\hline
\end{tabular}


Table 2. Bivariate analyses of factors associated with $A$. baumannii infection in ICU patients in a Public Hospital in Paraná, Brazil, from January 2018 to December 2020.

\begin{tabular}{|c|c|c|c|c|c|}
\hline \multirow[b]{2}{*}{ Continuous variables } & \multirow{2}{*}{$\begin{array}{l}\text { Case }(n=68) \\
\text { Mean/Median }\end{array}$} & \multicolumn{4}{|c|}{ Control $(n=136)$} \\
\hline & & $\mathrm{DP} / \mathrm{IQ}$ & Mean/Median & $\mathrm{DP} / \mathrm{IQ}$ & $\mathrm{p}$ \\
\hline Hospital stays (days) & $34.8 / 35$ & $17.2 / 22$ & $23.8 / 22$ & $11.5 / 14$ & $<0.001$ \\
\hline ICU stays (days) & $25.4 / 23$ & $15.5 / 19$ & $16.8 / 16$ & $6.8 / 10$ & $<0.001$ \\
\hline $\begin{array}{l}\text { Estimated mortality } \\
\text { percentage-APACHE-II }\end{array}$ & $45.3 / 47$ & $21.3 / 27$ & $41.9 / 40$ & $21.7 / 31$ & 0.200 \\
\hline Number of morbidities & $1.4 / 1$ & $1.3 / 2$ & $1.3 / 1$ & $1.3 / 2$ & 0.570 \\
\hline CVC Days & $28.7 / 25$ & $15.2 / 20$ & $18.8 / 18$ & $9.5 / 12$ & $<0.001$ \\
\hline SVD Days & $30.9 / 29$ & $16.1 / 21$ & $21.1 / 20$ & $10.2 / 13$ & $<0.001$ \\
\hline VM Days & $21.4 / 17$ & $15.6 / 17$ & $11.9 / 12$ & $8.6 / 13$ & $<0.001$ \\
\hline Categorical variables & $\mathbf{n}$ & $\%$ & $\mathbf{n}$ & $\%$ & $\mathrm{p}$ \\
\hline $\begin{array}{l}\text { Form of hospital } \\
\text { admission }\end{array}$ & & & & & $<0.001$ \\
\hline Community & 36 & 52.9 & 115 & 84.6 & \\
\hline $\begin{array}{l}\text { Transfer of another } \\
\text { health unit }\end{array}$ & 32 & 47.1 & 21 & 15.4 & \\
\hline Recent prior & & & & & 0.011 \\
\hline \multicolumn{6}{|l|}{ hospitalization } \\
\hline No & 33 & 48.5 & 91 & 66.9 & \\
\hline Yes & 35 & 51.5 & 45 & 33.1 & \\
\hline Colonization & & & & & $<0.001$ \\
\hline No & 43 & 63.2 & 128 & 94.1 & \\
\hline Yes & 25 & 36.8 & 8 & 5.9 & \\
\hline Surgical procedure & & & & & 0.013 \\
\hline No & 32 & 47.1 & 90 & 66.2 & \\
\hline Yes & 36 & 52.9 & 46 & 33.8 & \\
\hline Hemodialysis & & & & & 0.468 \\
\hline No & 47 & 69.1 & 102 & 75.0 & \\
\hline Yes & 21 & 30.9 & 34 & 25.0 & \\
\hline Enteral tube & & & & & 0.011 \\
\hline No & 2 & 2.9 & 22 & 16.2 & \\
\hline Yes & 66 & 97.1 & 114 & 83.8 & \\
\hline $\begin{array}{l}\text { Use of previous } \\
\text { antimicrobial }\end{array}$ & & & & & 0.265 \\
\hline No & 2 & 2.9 & 11 & 8.1 & \\
\hline Yes & 66 & 97.1 & 125 & 91.9 & \\
\hline
\end{tabular}

Note. DP, standard deviation; IQ, interquartile range; CVC, central venous catheter; SVD, vesical catheter; VM, mechanical ventilation. 
Table 3. Crude and adjusted models of factors associated with $A$. baumannii infection in patients hospitalized in an ICU in a Public Hospital of Paraná, Brazil, from January 2018 to December 2020.

\begin{tabular}{|c|c|c|c|c|}
\hline Risk factors & $\begin{array}{l}\text { Crude OR } \\
(95 \% \mathrm{CI})\end{array}$ & $\mathrm{p}$ & $\begin{array}{c}\text { Adjusted OR } \\
(95 \% \mathrm{CI})\end{array}$ & $\mathrm{p}$ \\
\hline Hospital stays (days) & $1.06(1.03-1.08)$ & $<0.001$ & $1.06(1.03-1.08)$ & $<0.001$ \\
\hline ICU stay (days) & $1.08(1.04-1.12)$ & $<0.001$ & - & - \\
\hline CVC Days & $1.07(1.04-1.10)$ & $<0.001$ & - & - \\
\hline SVD Days & $1.06(1.03-1.09)$ & $<0.001$ & - & - \\
\hline VM Days & $1.08(1.04-1.11)$ & $<0.001$ & - & - \\
\hline \multicolumn{5}{|l|}{$\begin{array}{l}\text { Form of hospital } \\
\text { admission }\end{array}$} \\
\hline Community & 1 & & 1 & \\
\hline \multicolumn{5}{|l|}{$\begin{array}{l}\text { Recent prior } \\
\text { hospitalization }\end{array}$} \\
\hline No & 1 & & & \\
\hline Yes & $2.24(1.23-4.06)$ & 0.008 & - & - \\
\hline \multicolumn{5}{|l|}{ Colonization } \\
\hline No & 1 & & 1 & \\
\hline Yes & $9.60(4.03-22.89)$ & $<0.001$ & $9.32(3.52-24.72)$ & $<0.001$ \\
\hline \multicolumn{5}{|l|}{ Surgical procedure } \\
\hline No & 1 & & & \\
\hline Yes & $2.09(1.15-3.78)$ & 0.015 & - & - \\
\hline \multicolumn{5}{|l|}{ Enteral catheter } \\
\hline No & 1 & & & \\
\hline Yes & $6.22(1.42-27.29)$ & 0.015 & - & - \\
\hline
\end{tabular}

Note. Crude OR, the odds ratio of bivariate analyses; Adjusted OR, the odds ratio of the multivariate analysis; $\mathrm{CI}$, confidence interval; $\mathrm{CVC}$, central venous catheter; SVD, vesical catheter; VM, mechanical ventilation.

and unfavorable clinical outcomes. Economic burdens and physical, functional, and psychological consequences are also substantial [2] [17].

Our study is in agreement with epidemiological data of other studies that indicate that $A$. baumannii is responsible for $54 \%$ of ICU infections and $5 \%$ in internal wards [5]. A systematic review with a meta-analysis conducted in African, Eastern Mediterranean, and European regions demonstrated that infections by A. baumannii in the ICU corresponded to $15.3 \%$ (95\% CI $11.7 \%-19.7 \%$ ) of all infections, being $20.9 \%$ (95\% CI $16.5 \%-26.2 \%$ ) in ICUs and $16.3 \%$ in clinical wards (95\% CI 8.0\% - 30.5\%) [18]. Furthermore, the incidence and prevalence of A. baumannii infections are $10-50$ times lower in studies covering the entire 
hospital than in those based only on the ICU [18]. In Brazil, most of the studies surveyed were developed in ICUs [6] [7] [8] [19] [20].

All clinical isolates in our study were resistant to carbapenems and demonstrated an increase in resistance to aminoglycosides and penicillin with beta-lactams over the years. None showed resistance to polymyxin. Two hundred and eleven (211) laboratories in 20 European countries recorded rates of more than $50 \%$ of clinical isolates with carbapenem-resistant $A$. baumannii between 2015 and 2017. Most laboratories were in Greece $(\mathrm{n}=12)$, Turkey $(\mathrm{n}=11)$, Italy $(\mathrm{n}=9)$ and Romania $(\mathrm{n}=7)$ [21]. A multicenter study in Serbia showed that 280 out of the 2.401 clinical samples studied had the presence of $A$. baumannii. Two hundred and twenty-seven (227) of the isolates were sensitive to colistin (95.7\%), 178 to tigecycline (75.1\%), and 10 were classified as drug multiresistant [5]. In Latin America, the carbapenem resistance rate was $90 \%$ for $A$. baumannii in different countries between 2002 and 2013 [22]. Data from the Central Laboratory of the State of Paraná highlighted A. baumannii as the fifth most frequent infectious agent in 2019, and the second in 2020, with high rates of resistance to carbapenems and with increasing resistance to polymyxin [10] [11].

Records from the SENTRY Antimicrobial Surveillance Program (2016 to 2019) showed increased meropenem susceptibility between 2016 (34.7\%) and 2019 (71.0\%) in Western Europe and from 54.6\% to 70.4\% during the same period in the United States [23]. Colistin and tobramycin were active in more than $50 \%$ of the isolates [23]. Other studies conducted in Germany and Lebanon have demonstrated, however, reduced resistance over the years added to continuous efforts in antimicrobial and infection control and prevention measures [24] [25]. Studies suggest that treatment with varied antimicrobials and extensive use of carbapenems, piperacillin/tazobactam, and vancomycin increased the resistance profile of strains year by year [26] [27]. However, there is insufficient data to define a combination of antibiotics for treatment for that microorganism. The recommendation in the literature is to combine antibiotics to obtain synergism of antibacterial activity, thus amplifying their efficacy [28] [29].

The risk factors for $A$. baumannii in the ICU were colonization, transfer of another unit, and the time of hospitalization. The colonization was the greatest factor, being in cases 10 times greater than in controls. Colonized or infected patients represent reservoirs for horizontal transmission and dissemination of multi-resistant mainly in ICUs [8] [30] [31] [32]. A high rate of colonization during ICU stay is associated with transmission among patients through the health team, objects and environmental surfaces, medical devices, and ineffective infection control measures [32]. Health teams working in different institutions within the same city can be facilitators for the occurrence of this transmission [8].

The transfer of another health unit increased 5 times the chances of infection. Indeed, a 10-year longitudinal study in Central Europe identified that, out of a total of 76 patients colonized at admission ( $56 \%$ by A. baumannii), $24 \%(\mathrm{n}=16)$ came from countries outside the European Union [33]. 
We identified that each day of hospitalization increased by $6 \%$ the chances of acquiring the infection by $A$. baumannii. Longer hospital stay has been associated with high mortality rates in the ICU [12] [34] [35] [36]. Colonization and infection by carbapenem-resistant enterobacteria also prolong the time of hospitalization and are associated with higher mortality rates between $25 \%$ and $70 \%$ [34] [35] [37] [38].

Importantly, the estimate of mortality calculated by APACHE II at admission had a negligible difference between cases and controls (mean/median 45.3/47 vs. 41.9/40). Nonetheless, we found that the mortality in cases was $51.5 \%(35 / 68)$ compared to $39.7 \%(54 / 136)$ in controls. This is nearly $12 \%$ higher among cases, and the infection is suspected to be a contributing factor to death. In this sense, the EPIC II study (2007), including 1.265 ICUs patients from 75 countries reported an ICU mortality rate in infected patients twice as high when compared to uninfected patients $(25 \%$ [1688/6659] vs. $11 \%$ [682/6352], respectively; $\mathrm{p}<0.001)$, as well as the hospital mortality rate (33\% [2201/6659] vs. $15 \%$ [942/6352]; $\mathrm{p}<0.001$ ), respectively [35]. Another international study in 2017 conducted in 1.150 centers from 88 countries demonstrated that carbapenem-resistant Acinetobacter infections (OR $=1.40$ [95\% CI, $1.08-1.81] ; \mathrm{p}=$ 0.01 ) were independently associated with a high risk of death when compared to infection by another microorganism [39]. High mortality rates are identified in other countries as well, ranging from $74.1 \%$ in Morocco and between $43.7 \%$ to $81 \%$ in Brazil [7] [19] [40].

In the bivariate analysis, the factors associated with $A$. baumannii infection were the time of hospitalization, longer ICU time, longer number of days using invasive devices (CVC, SVD, and VM), admission by transfer from another health unit, previous hospitalization, colonization, surgical procedure, and use of the enteral tube. National and international studies corroborate the factors associated with $A$. baumannii infection found in this study, the most frequently reported being: length of stay in the ICU [33] [35]-[40], central venous catheterization [38] [40] [41] [42], mechanical ventilation [37] [38] [40] [42], urinary device [38] [40] [41] [42], use of the enteral tube [25] [32] [37] [41] [43] and previous use of antimicrobials [6] [20] [25] [35]-[41] [43]. Those with lower frequency were invasive procedure [40], previous colonization [38], comorbidities [19] [38] [39], APACHE-II scores [39] [41] [43], hemodialysis [25] [38] [39], and SOFA score [19].

The use of invasive devices for a long time has been associated with the extraordinary ability to form biofilm and with the survival of $A$. baumannii on abiotic surfaces of medical and non-medical objects, in dry or humid environments [5] [44] [45]. One of the important virulence factors of $A$. baumannii, fibronectin-binding proteins (FPBs), is the main responsible for the pathogen's adhering to implantable materials [46]. While the formation of type I pili (CSU pili) is essential in the formation of biofilms and their maintenance on abiotic surfaces such as polystyrene [47]. Indeed, prolonged contact of biofilm with the host has been reported as the cause of outbreaks of medical device-related infec- 
tions and ventilatory-associated pneumonia [48].

Use of mechanical ventilation was significantly higher in cases than in controls (mean/median $21.4 / 17$ vs. 11.9/12) as well as respiratory tract infections $(46 / 69,67.11 \%)$. A previous study in the same institution also showed a higher prevalence of pneumonia associated with mechanical ventilation $(\mathrm{OR}=4.48$; IC 95\%: 1.55 - 13.00; $p=006$ ) [12]. In other countries, the incidence density of ventilator-associated pneumonia (VAP/1000 patient-days) ranged from 8.9 to 39.6 in Saudi Arabia, 11.8 in India, 14.7 in Southeast Asia, 15.2 in Poland, 21.40 in Nepal, and 36.3 in Brazil [19] [36] [41] [49] [50] [51]. These studies confirm the association of longer use of invasive devices, especially time on mechanical ventilation, as an important risk factor for ventilator-associated pneumonia caused by $A$. baumannii.

Few studies have verified the use of an enteral tube as an invasive device that can contribute significantly to the colonization of the gastrointestinal tract by eliminating the gastric barrier. The use of an enteral tube was independently associated with $A$. baumannii infection in this study. We were able to find some studies that also corroborate this finding [20] [32]. An in vitro study showed that the $\mathrm{PH}$ of hydrochloric acid $(<4 \%)$ was able to eliminate $99.9 \%$ of enterobacteria in 30 minutes and constitutes one of the barriers to the progression of these bacteria to the intestinal tract [52]. Other studies also point to gastric acid suppression as a risk factor for colonization of the gastrointestinal tract by multidrug-resistant enterobacteria, especially in the use of proton pump inhibitors [53] [54] [55]. In this context, the enteral tube circumvents and buffers the natural barrier imposed by gastric acid and may contribute to intestinal colonization of $A$. baumannii [55].

\section{Conclusion}

The study showed an increase in the incidence of infection accompanied by increased antimicrobial resistance year by year in the study period. The risk factors associated with infection were colonization, transfer from another health unit, and hospitalization time. As therapeutic options have become limited due to increasing reports of infection by multidrug-resistant $A$. baumanni, there are challenges for planning prevention actions focused on institutional reality. Therefore, the knowledge of risk factors for infection in health institutions is essential to implement measures aiming to prevent the chain of transmission of infections by $A$. baumannii.

\section{Conflicts of Interest}

The authors declare no conflicts of interest regarding the publication of this paper.

\section{References}

[1] Nutman, A., Glick, R., Temkin, E., Hoshen, M., Edgar, R., Braun, T., et al. (2014) 
A Case-Control Study to Identify Predictors of 14-Day Mortality Following Car-Bapenem-Resistant Acinetobacter baumannii Bacteremia. Clinical Microbiology and Infection, 20, O1028-O1034. https://doi.org/10.1111/1469-0691.12716

[2] Chagas, T.P.G. (2015) Characterization of Acinetobacter spp. Multirresistentes Produtores de carbapenemases, do tipo OXA e NDM, isolados de diferentes regiões do Brasil. Ph.D. Thesis, Fiocruz, Brasil.

https://www.arca.fiocruz.br/bitstream/icict/23208/2/thiago chagas ioc dout 2015. pdf

[3] Ayoub Moubareck, C. and Hammoudi Halat, D. (2020) Insights into Acinetobacter bau mannii: A Review of Microbiological, Virulence, and Resistance Traits in a Threatening Nosocomial Pathogen. Antibiotics, 9, Article No. 119.

https://doi.org/10.3390/antibiotics9030119

https://www.mdpi.com/2079-6382/9/3/119

[4] BRASIL (2018) National Action Plan for The Prevention and Control of Antimicrobial Resistance in the Scope of Single Health 2018-2022.

https://portalarquivos2.saude.gov.br/images/pdf/2018/dezembro/20/af-pan-br-17de z18-20x28-csa.pdf

[5] Lukovic, B., Gajic, I., Dimkic, I., Kekic, D., Zornic, S., Pozder, T., et al. (2020) The First Nationwide Multicenter Study of Acinetobacter baumannii Recovered in Serbia: Emergence of OXA-72, OXA-23 and NDM-1-Producing Isolates. Antimicrobial Resistance \& Infection Control, 9, Article No. 101.

https://doi.org/10.1186/s13756-020-00769-8

[6] Neves, F.C., Clemente, W.T., Lincopan, N., Paião, I.D., Neves, P.R., Romanelli, R.M., et al. (2016) Clinical and Microbiological Characteristics of OXA-23- and OXA-143-Producing Acinetobacter baumannii in ICU Patients at a Teaching Hospital, Brazil. The Brazilian Journal of Infectious Diseases, 20, 556-563. https://doi.org/10.1016/j.bjid.2016.08.004

[7] de Azevedo, F.K.S.F., Dutra, V., Nakazato, L., Pepato, M.A., de Sousa, A.T.H.I., de Azevedo, C.C.S.F., et al. (2019) New Sequence Types of Acinetobacter baumannii in Two Emergency Hospitals in the Central-West Region of Brazil. Revista da Sociedade Brasileira de Medicina Tropical, 52, Article ID: e0176790. https://doi.org/10.1590/0037-8682-0077-2019

[8] Castilho, S.R.A., de Godoy, C.S.M., Guilarde, A.O., Cardoso, J.L., André, M.C.P., Junqueira-Kipnis, A.P., et al. (2017) Acinetobacter baumannii Strains Isolated from Patients in Intensive Care Units in Goiânia, Brazil: Molecular and Drug Susceptibility Profiles. PLoS ONE, 12, Article ID: e0176790.

https://doi.org/10.1371/journal.pone.0176790

[9] PARANÁ (Estado) (2018) Boletim Informativo Avaliação dos Indicadores Estaduais das Infecções Relacionadas à Assistência à Saúde, Resistência Microbianae Consumo de Antimicrobianos no Paraná, notificados no Sistema Online de Notificação de Infecções Hospitalares (SONIH) de janeiro a junho de 2018.

https://www.saude.pr.gov.br/sites/default/arquivos restritos/files/documento/202102/boletimsonih jan jul 2018.pdf

[10] PARANÁ (Estado) (2019) Boletim SONIH: Boletim Epidemiologico das IRAS. https://www.saude.pr.gov.br/sites/default/arquivos restritos/files/documento/202102/boletim sonih resumido 15 05 2020.pdf

[11] PARANÁ (Estado) (2020) Boletim SONIH: Boletim Epidemiologico das IRAS. https://www.saude.pr.gov.br/sites/default/arquivos restritos/files/documento/202106/boletim informativo - sonih 2020 - versao final ceciss-pr.pdf

[12] Vandresen, D.F., Lucio, L.C., Yamada, R.S., Vieira, A.P., Follador, F.A.C., Benedetti, 
V.P., et al. (2021) Associated Factors of Acinetobacter baumannii Complex in Hospitalized Patients: A Case-Control Study. The Journal of Infection in Developing Countries, 15, 73-80. https://doi.org/10.3855/jidc.13525

[13] CLSI (Clinical \& Laboratory Standards Institute) (2018) M100-Performance Standards for Antimicrobial Susceptibility Testing. 28th Edition, Clinical \& Laboratory Standards Institute, Wayne, PA, USA.

https://clsi.org/media/1930/m100ed28 sample.pdf

[14] EUCAST (European Committee on Antimicrobial Susceptibility Testing) (2018, July 15) Information or NACs-Redefining Antimicrobial Susceptibility Testing Categories.

https://www.eucast.org/fileadmin/src/media/PDFs/EUCAST files/Consultation/201 8/Information for NACs - Redefining antimicrobial susceptibility testing categ ories.pdf

[15] PARANÁ (Estado) (2010) SESA Resolução No. 0674/2010: Aprova o regulamento técnico que estabelece as ações de vigilância em saúde a serem desenvolvi das no Controle das Bactérias Multirresistentes (BMR) e Bactérias oriundas de Infecções Hospitalares e de Surtos em Serviços de Saúde.

https://www.saude.pr.gov.br/sites/default/arquivos restritos/files/documento/202004/resolucao6742010.pdf

[16] PARANÁ (Estado) (2018) Resolução SESA No. 096/2018 Estabelece as ações de vigilância em saúde a serem desenvolvidas no controle de Microrganismos Multirresistentes (MMR) e Surtos decorrentes de Infecções Relacionadas à Assistência à Saúde (IRAS) em Estabelecimentos de Assistência à Saúde (EAS) no Paraná. https://www.saude.pr.gov.br/sites/default/arquivos restritos/files/documento/202004/96 18.pdf

[17] Chusri, S., Chongsuvivatwong, V., Silpapojakul, K., Singkhamanan, K., Hortiwakul, T., Charernmak, B., et al. (2019) Clinical Characteristics and Outcomes of Community and Hospital-Acquired Acinetobacter baumannii Bacteremia. Journal of Microbiology, Immunology, and Infection, 52, 796-806.

https://doi.org/10.1016/j.jmii.2019.03.004

[18] Ayobami, O., Willrich, N., Harder, T., Okeke, I.N., Eckmanns, T. and Markwart, R. (2019) The Incidence and Prevalence of Hospital-Acquired (Carbapenem-Resistant) Acinetobacter baumannii in Europe, Eastern Mediterranean and Africa: A Systematic Review and Meta-Analysis. Emerging Microbes \& Infections, 8, 1747-1759. https://doi.org/10.1080/22221751.2019.1698273

[19] Bento Talizin, T., Dantas de Maio Carrilho, C.M., Magalhães Carvalho Grion, C., Tibery Queiroz Cardoso, L., Toshiyuki Tanita, M., Boll, K.M., et al. (2020) Polymyxin for Treatment of Ventilator-Associated Pneumonia in a Setting of High Carbapenem Resistance. PLoS ONE, 15, Article ID: e0237880.

https://doi.org/10.1371/journal.pone.0237880

[20] da Silva, K.E., Maciel, W.G., Croda, J., Cayô, R., Ramos, A.C., de Sales, R.O., et al. (2018) A High Mortality Rate Associated with Multidrug-Resistant Acinetobacter baumannii ST79 and ST25 carrying OXA-23 in a Brazilian Intensive Care Unit. PLoS ONE, 13, Article ID: e0209367. https://doi.org/10.1371/journal.pone.0209367

[21] Kostyanev, T., Vilken, T., Lammens, C., Timbermont, L., Van't Veen, A. and Goossens H. (2019) Detection and Prevalence of Carbapenem-Resistant Gram-Negative Bacteria among European Laboratories in the COMBACTE Network: A COMBACTE LAB-Net Survey. International Journal of Antimicrobial Agents, 53, 268-274. https://doi.org/10.1016/j.ijantimicag.2018.10.013

[22] Labarca, J.A., Salles, M.J.C., Seas, C. and Guzmán-Blanco, M. (2016) Carbapenem 
Resistance in Pseudomonas aeruginosa and Acinetobacter baumannii in the Nosocomial Setting in Latin America. Critical Reviews in Microbiology, 42, 276-292. https://doi.org/10.3109/1040841X.2014.940494

[23] Sader, H.S., Streit, J.M., Carvalhaes, C.G., Huband, M.D., Shortridge, D., Mendes, R.E., et al. (2021) Frequency of Occurrence and Antimicrobial Susceptibility of Bacteria Isolated from Respiratory Samples of Patients Hospitalized with Pneumonia in Western Europe, Eastern Europe, and the USA: Results from the SENTRY Antimicrobial Surveillance Program (2016-19). JAC-Antimicrobial Resistance, 3, Article No. dlab117. https://doi.org/10.1093/jacamr/dlab117

[24] Said, D., Willrich, N., Ayobami, O., Noll, I., Eckmanns, T. and Markwart R. (2021) The Epidemiology of Carbapenem Resistance in Acinetobacter baumannii Complex in Germany (2014-2018): An Analysis of Data from the National Antimicrobial Resistance Surveillance System. Antimicrobial Resistance \& Infection Control, 10, Article No. 45. https://doi.org/10.1186/s13756-021-00909-8

[25] Moghnieh, R., Araj, G.F., Awad, L., Daoud, Z., Mokhbat, J.E., Jisr, T., et al. (2019) A Compilation of Antimicrobial Susceptibility Data from a Network of 13 Lebanese Hospitals Reflecting the National Situation during 2015-2016. Antimicrobial Resistance \& Infection Control, 8, Article No. 41. https://doi.org/10.1186/s13756-019-0487-5

[26] Li, S., Li, H., Qi, T., Yan, X., Wang, B., Guan, J., et al. (2017) Comparative Transcriptomics Analyses of the Different Growth States of Multidrug-Resistant Acinetobacter baumannii. Biomedicine \& Pharmacotherapy, 85, 564-574. https://doi.org/10.1016/j.biopha.2016.11.065

[27] Balkhy, H.H., El-Saed, A., Alshamrani, M.M., Alsaedi, A., Al Nasser, W., El Gammal, A., et al. (2020) Ten-Year Resistance Trends in Pathogens Causing Healthcare-Associated Infections; Reflection of Infection Control Interventions at a Multi-Hospital Healthcare System in Saudi Arabia, 2007-2016. Antimicrobial Resistance \& Infection Control, 9, Article No. 21. https://doi.org/10.1186/s13756-020-0678-0

[28] Towner, K.J. (2009) Acinetobacter: An Old Friend, but a New Enemy. Journal of Hospital Infection, 73, 355-363. https://doi.org/10.1016/j.jhin.2009.03.032

[29] Mota, F.S., Oliveira, H.A. and Souto, R.C.F. (2018) Perfil e prevalência de resistência aos antimicrobianos de bactérias gram-negativas isoladas de pacientes de uma unidade de terapia intensiva. RBAC Magazine, 50, 270-277.

[30] Agência Nacional de Vigilância Sanitária (2017) Investigação e controle de bactérias multiresistentes.

Https://www.anvisa.gov.br/servicosaude/controle/reniss/manual\%20 controle bact erias.pdf

[31] Agência Nacional de Vigilância Sanitária (2013) Nota Técnica No 01/2013: Medidas de prevenção e controle de infecções por enterobactérias multiresistentes.

https://cevs.rs.gov.br/upload/arquivos/201706/30132435-1369161512-nota-tec-01-2 013-anvisa.pdf

[32] Kiddee, A., Assawatheptawee, K., Naudom, A., Treebupachatsakul, P., Wangteeraprasert, A., Walsh, T.R., et al. (2018) Risk Factors for Gastrointestinal Colonization and Acquisition of Carbapenem-Resistant Gram-Negative Bacteria among Patients in Intensive Care Units in Thailand. Antimicrobial Agents and Chemotherapy, 62, e00341-18. https://doi.org/10.1128/AAC.00341-18

[33] Segagni Lusignani, L., Starzengruber, P., Dosch, V., Assadian, O., Presterl, E. and Diab-Elschahawi, M. (2017) Molecular Epidemiology of Multidrug-Resistant Clinical Isolates of Acinetobacter baumannii. Wiener klinische Wochenschrift, 129, 
816-822. https://doi.org/10.1007/s00508-017-1242-7

[34] Tischendorf, J., de Avila, R.A. and Safdar, N. (2016) Risk of Infection Following Colonization with Carbapenem-Resistant Enterobacteriaceae: A Systematic Review. American Journal of Infection Control, 44, 539-543. https://doi.org/10.1016/j.ajic.2015.12.005

[35] Vincent, J.-L., Rello, J., Marshall, J., Silva, E., Anzueto, A., Martin, C.D., et al. (2009) International Study of the Prevalence and Outcomes of Infection in Intensive Care Units. JAMA, 302, 2323-2329. https://doi.org/10.1001/jama.2009.1754

[36] Vincent, J.L., Bihari, D.J., Suter, P.M., Bruining, H.A., White, J., Nicolas-Chanoin, M.H., et al. (1995) The Prevalence of Nosocomial Infection in Intensive Care Units in Europe. Results of the European Prevalence of Infection in Intensive Care (EPIC) Study. JAMA, 274, 639-644. https://doi.org/10.1001/jama.1995.03530080055041

[37] Vázquez-López, R., Solano-Gálvez, S.G., Juárez Vignon-Whaley, J.J., Abello Vaamonde, J.A., Padró Alonzo, L.A., Rivera Reséndiz, A., et al. (2020) Acinetobacter baumannii Resistance: A Real Challenge for Clinicians. Antibiotics, 9, Article No. 205. https://doi.org/10.3390/antibiotics9040205

[38] Palacios-Baena, Z.R., Giannella, M., Manissero, D., Rodríguez-Baño, J., Viale, P., Lopes, S., et al. (2020) Risk Factors for Carbapenem-Resistant Gram-Negative Bacterial Infections: A Systematic Review. Clinical Microbiology and Infection, 27, 228-235. https://doi.org/10.1016/j.cmi.2020.10.016

[39] Vincent, J.-L., Sakr, Y., Singer, M., Martin-Loeches, I., Machado, F.R., Marshall, J.C., et al. (2020) Prevalence and Outcomes of Infection among Patients in Intensive Care Units in 2017. JAMA, 323, 1478-1487. https://doi.org/10.1001/jama.2020.2717

[40] Uwingabiye, J., Lemnouer, A., Baidoo, S., Frikh, M., Kasouati, J., Maleb, A., et al. (2017) Intensive Care Unit-Acquired Acinetobacter baumannii Infections in a Moroccan Teaching Hospital: Epidemiology, Risk Factors, and Outcome. Germs, 7, 193-205. https://doi.org/10.18683/germs.2017.1126

[41] Kumar, S., Sen, P., Gaind, R., Verma, P.K., Gupta, P., Suri, P.R., et al. (2018) Prospective Surveillance of Device-Associated Health Care-Associated Infection in an Intensive Care Unit of a Tertiary Care Hospital in New Delhi, India. American Journal of Infection Control, 46, 202-206. https://doi.org/10.1016/j.ajic.2017.08.037

[42] Parajuli, N.P., Acharya, S.P., Dahal, S., Singh, J.P., Mishra, S.K., Kattel, H.P., et al. (2017) Epidemiology of Device-Associated Infections in an Intensive Care Unit of a Teaching Hospital in Nepal: A Prospective Surveillance Study from a Developing Country. American Journal of Infection Control, 45, 1024-1029. https://doi.org/10.1016/j.ajic.2017.02.040

[43] Qiao, F., Huang, W., Gao, S., Cai, L., Zhu, S., Wei, L., et al. (2020) Risk Factor for Intestinal Carriage of Carbapenem-Resistant Acinetobacter baumannii and the Impact on Subsequent Infection among Patients in an Intensive Care Unit: An Observational Study. BMJ Open, 10, Article ID: e035893.

https://doi.org/10.1136/bmjopen-2019-035893

[44] Ramirez, M.S., Bonomo, R.A. and Tolmasky, M.E. (2020) Carbapenemases: Transforming Acinetobacter baumannii into a Yet More Dangerous Menace. Biomolecules, 10, Article No. 720. https://doi.org/10.3390/biom10050720

[45] Avila-Novoa, M.-G., Solís-Velázquez, O.-A., Rangel-López, D.-E., González-Gómez, J.-P., Guerrero-Medina, P.-J. and Gutiérrez-Lomelí, M. (2019) Biofilm Formation and Detection of Fluoroquinolone- and Carbapenem-Resistant Genes in Multidrug-Resistant Acinetobacter baumannii. Canadian Journal of Infectious Diseases and Medical Microbiology, 2019, Article ID: 3454907. 
https://doi.org/10.1155/2019/3454907

[46] Smani, Y., McConnell, M.J. and Pachón, J. (2012) Role of Fibronectin in the Adhesion of Acinetobacter baumannii to Host Cells. PLoS ONE, 7, Article ID: e33073. https://doi.org/10.1371/journal.pone.0033073

[47] Eze, E.C., Chenia, H.Y. and Zowalaty, M.E. (2018) Acinetobacter baumannii Biofilms: Effects of Physicochemical Factors, Virulence, Antibiotic Resistance Determinants, Gene Regulation, and Future Antimicrobial Treatments. Infection and Drug Resistance, 11, 2277-2299. https://doi.org/10.2147/IDR.S169894

[48] Ryu, S.Y., Baek, W.-K. and Kim, H.A. (2017) Association of Biofilm Production with Colonization among Clinical Isolates of Acinetobacter baumannii. The Korean Journal of Internal Medicine, 32, 345-351. https://doi.org/10.3904/kjim.2015.287

[49] Gaid, E., Assiri, A., McNabb, S. and Banjar W. (2018) Device-Associated Nosocomial Infection in General Hospitals, Kingdom of Saudi Arabia, 2013-2016. Journal of Epidemiology and Global Health, 7, S35-S40.

https://doi.org/10.1016/j.jegh.2017.10.008

[50] Ling, M.L., Apisarnthanarak, A. and Madriaga, G. (2015) The Burden of Healthcare-Associated Infections in Southeast Asia: A Systematic Literature Review and Meta-Analysis. Clinical Infectious Diseases, 60, 1690-1699. https://doi.org/10.1093/cid/civ095

[51] Kołpa, M., Wałaszek, M., Gniadek, A., Wolak, Z. and Dobroś W. (2018) Incidence, Micro-Biological Profile and Risk Factors of Healthcare-Associated Infections in Intensive Care Units: A 10 Year Observation in a Provincial Hospital in Southern Poland. International Journal of Environmental Research and Public Health, 15, Article No. 112. https://doi.org/10.3390/ijerph15010112

[52] Giannella, R.A., Broitman, S.A. and Zamcheck, N. (1972) Gastric Acid Barrier to Ingested Microorganisms in Man: Studies in Vivo and in Vitro. Gut, 13, 251-256. https://doi.org/10.1136/gut.13.4.251

[53] Willems, R.P.J., van Dijk, K., Ket, J.C.F. and Vandenbroucke-Grauls, C.M.J.E. (2020) Evaluation of the Association between Gastric Acid Suppression and Risk of Intestinal Colonization with Multidrug-Resistant Microorganisms. JAMA Internal Medicine, 180, 561-571. https://doi.org/10.1001/jamainternmed.2020.0009

[54] Huizinga, P., van den Bergh MK, van Rijen, M., Willemsen, I., van't Veer, N. and Kluytmans J. (2017) Proton Pump Inhibitor Use Is Associated with Extended-Spectrum $\beta$-Lactamase-Producing Enterobacteriaceae Rectal Carriage at Hospital Admission: A Cross-Sectional Study. Clinical Infectious Diseases, 64, 361-363. https://doi.org/10.1093/cid/ciw743

[55] Donskey, C.J. (2004) The Role of the Intestinal Tract as a Reservoir and Source for Transmission of Nosocomial Pathogens. Clinical Infectious Diseases, 39, 219-226. https://doi.org/10.1086/422002 